\title{
Studies in Value Theory
}

Preface

Chapter 1: VALUES AND THE EXPLANATION

OF BEHAVIOUR 1

Chapter 2: ON THE IMPORT AND RATIONALE OF VALUE ATTRIBUTION

Chapter 3: HOW WIDE IS THE GAP BETWEEN FACTS AND VALUES?

Chapter 4: NOMIC HIERARCHIES AND PROBLEMS OF RELATIVISM

Chapter 5: BY THE STANDARDS OF THEIR DAY

Chapter 6: PRESUMPTION AND THE JUDGMENT OF ELITES 85

Chapter 7: DESIDERATUM COMPLEMENTARITY

Chapter 8: THE ROLE OF VALUES IN THE SOCIAL SCIENCES 111

Chapter 9: VALUES IN SCIENCE 
